\title{
VÁLLALATI ÖKOLÓGIAILÁBNYOM-SZÁMÍTÁS KIHÍVÁSAI A KKV-SZEKTORBAN
}

A tudományos és társadalmi diskurzus elsősorban a nagyvállalati szereplők környezeti teljesítményére irányul. Habár ezek a vállalatok rendszerint több országban tevékenykednek, az Európai Unióban létrehozott hozzáadott érték, valamint ebből kifolyólag a környezetkárosítás több, mint felét a kis- és középvállalkozások tevékenységéhez kapcsolható. Ugyanakkor míg a nagyvállalatok a környezeti teljesítmény méréséhez szükséges eszközöket és szakértelmet igénybe vehetik, addig a KKV-szektor számára e lehetőségek csupán korlátozottan állnak rendelkezésre.

A szerzők kutatásukban egy, a KKV-szektor sajátosságainak megfelelő ökológiailábnyom-kalkulátort dolgoztak ki, melyet hat különböző szektorban és szervezeti keretek között működő vállalkozás esetében teszteltek. Eredményeik alapján a társas vállalkozások vezetői információs rendszere tartalmazza mindazon főbb inputadatokat, melyek elegendőek a vállalkozás ökológiai lábnyomának becsléséhez. Az egyéni vállalkozók esetében ugyanakkor a szükséges adatok zöme csak becsléssel állítható elő.

A KKV-szektor környezeti teljesítményének nagyobb transzparenciája érdekében javasolható, hogy a társas vállalkozások éves beszámolójának kiegészítő melléklete összehasonlítható és konzisztens módon, természetes mértékegységben tartalmazza az ökológiai lábnyom számításához szükséges főbb input adatokat. Ezen információk, valamint a kidolgozott kalkulátor segítségével meghatározhatóvá válna az egyes szektorok átlagos környezetterhelése, mely megfelelő kiindulási pontot nyújthatna a vállalkozások környezeti szempontú beruházásaihoz. ${ }^{1}$

Kulcsszavak: ökológiai lábnyom, ökológiailábnyom-kalkulátor, kis- és középvállalkozások (KKV)

A z elmúlt évek során számos online eszközt hoztak létre kutatóintézetek és tanácsadó cégek a vállalati karbonlábnyom (szénlábnyom) számítására. Egyes kalkulátorok ingyenesen is elérhetők - főként a mikrovállakozásokat célozva - ezek általában egyszerüek, kevés időráfordítással és adatigénnyel kitölthetők. Pontosságukat, megbízhatóságukat tekintve azonban sok problémával találkozunk. A kalkulátorok létrehozóinak kettős kihívással kell szembenézniük: egyik oldalról, a vállalkozások jelentős részénél nem áll rendelkezésre a számviteli elöírásokat meghaladó részletes adatbázis a felhasznált anyagok és energia mennyiségéről, valamint az összetett módszertanok alkalmazására felkészült szakember sem áll rendelkezésre. Másik oldalról viszont gyakran túlzott leegyszerüsítések miatt az eredmények lesznek rendkívül pontatlanok. Az ideális kalkulátor egyszerüen kitölthető és kezelhető, de mégis jól tükrözi a tényleges karbonlábnyom nagyságát (Harangozó \& Szigeti, 2017). A kalkulátorok áttekintésének tapasztalata azt is megmutatta, hogy a KKV-k számára alkalmas (a szénlábnyom-számításhoz hasonló) online ökológiailábnyom-kalkulátor jelenleg nem áll rendelkezésre. Ez azért meglepő, mert az ökológiai lábnyom népszerü és sokat hivatkozott mutató (Csutora, 2011; Szigeti, 2016) és nagyvállalati ökológiailábnyom-kalkulációk készülnek már Magyarországon is (Tóth et al., 2018). Az ökológiailábnyom-mutató nagy előnyét jelenti, hogy a pénzhez, vagy a karbonlábnyomhoz hasonlóan széleskörüen alkalmazható, de velük szemben, itt pontosan értelmezhető a „túl nagy” fogalma, elkülöníthető a jó és a rossz fejlődés (Tóth \& Szigeti, 2016).

Kutatásunk célja egy olyan módszertan kidolgozása, mely lehetőséget nyújt a kis- és középvállalkozások ökológiai lábnyomának mérésére. E vállalkozási kör speciális gazdasági jellemzőire való tekintettel olyan kalkulátort kívántunk létrehozni, mely a magyarországi viszonyokra adaptált és megbízható eredményt ad amellett, hogy a kitöltéséhez nincs szükség jelentős többlet adatigényre. Ez azért fontos, mert a vállalkozások számára egyébként kedvező, egyszerüsített beszámolási, adózási lehetőségek miatt kevés primer adat áll rendelkezésre. A létrehozott kalkulátort hat, különböző szektorban és szervezeti keretek között müködő vállalkozás esetében teszteltük. Eredményeinket a kalkulátor, illetve az esettanulmányok kidolgozása során feltárt tapasztalatokra, valamint azok következményeire alapozzuk.

Tanulmányunk következő fejezetében összefoglaljuk az ökológiailábnyom-számítással kapcsolatos főbb elméleti kereteket. A második fejezetben a kutatásban alkalmazott módszertant, majd azt követően az esettanulmányok föbb következtetéseit mutatjuk be. A tanulmány végén javaslatokat fogalmazunk meg a KKV-szektor ökológiailábnyom-számításához kapcsolódóan.

\section{Elméleti keretek}

Az ökológiai lábnyom (ecological footprint, EF) mérőszám azt fejezi ki, hogy adott technológiai fejlettség

${ }^{1}$ A kutatási projektet az Emberi Erőforrások Minisztériuma Felsőoktatási Intézményi Kiválósági Programja és a Budapesti Gazdasági Egyetem között létrejött együttmüködési megállapodás (20405-3/2018/FEKUTSTART) támogatja. 
mellett egy emberi közösségnek milyen mennyiségü produktív földterületre van szüksége önmaga fenntartásához és a megtermelt hulladék elnyeléséhez. A mutatót alkotói a számítás kezdeteitől fogva különféle szinteken számítják (Wackernagel \& Rees, 1996). A rendelkezésre álló biológiai kapacitásnak és a fogyasztás területi igényének az összehasonlítására irányuló globális ökológiai lábnyomnak a számítása mellett készülnek országos, regionális, települési, vállalati szintü, termékre vonatkozó és egyéni ökológiailábnyom-kalkulációk is. Az egész világra és az országokra vonatkozó ökológiailábnyom-mutatót a Global Footprint Network (GFN) számítja és van egyéni ökológiailábnyom-kalkulátora is, vállalati szintü kalkulációkkal azonban nem foglalkoznak. Az ökológiai lábnyom koncepciót számos - részben jogos - kritika éri és használatát sok félreértés övezi. Az ökológiai lábnyom elismertsége a különböző alkalmazási területeken jelentősen eltér egymástól: míg a mutatót globális szinten kiemelkedően jó mutatónak tartják (Stiglitz, 2009), addig az egyéb alkalmazásait számos oldalról éri kritika (van den Bergh \& Verbruggen, 1999; McDonald \& Patterson, 2004). A GFN koncepciója szerint az EF-indikátor hat fö földhasználati kategóriából áll: szántó, legelő, erdő, a halászati területek, beépített terület és a széndioxid-megkötéshez szükséges energiaföld. Az összes fogyasztást földhasználati kategóriánként veszi számba, majd az ekvivalenciafaktorok (Equivalence Factor, EQF) segítségével átváltja világátlag termőképességű földterületbe, globális hektárba (gha). Ez a váltószám arra szolgál, hogy például egy szántóterület és egy erdő összevethető legyen. Ha egy országra kívánjuk elvégezni a számítást, a hozamfaktorok (Yield Factor, YF) segítségével tudjuk összehasonlítani az egyes földhasználati kategóriákon belüli területi különbségeket, például egy magyar és egy görög szántóföld produktivitását (Lin et al., 2018). Az egyes szorzószámok évről évre kismértékben változhatnak, de nagyságrendjüket tekintve állandóak.

A vállalati alkalmazások alapirodalma 2000-ben jelent meg Sharing Nature's Interest: Ecological Footprints as an Indicator of Sustainability címmel, három szerzője között szerepel az ökológiailábnyom-koncepció megalkotója Mathis Wackernagel, valamint a Best Foot Forward (BFF) két alapítója, Nicky Chambers és Craig Simmons. A könyv példákat mutat a különböző típusú ökológiailábnyom-kalkulációkra, egyetemi, középiskolai és vállalati számításokra, valamint termékek ökológiai lábnyomának számítására (Chambers et al., 2000). Máig ez a könyv tekinthető kiindulási alapnak, az országos szint alatti számítások tervezéséhez.

A vállalati ökológiailábnyom- és szénlábnyom-számítás meghatározó szereplője volt a BFF, amely Európa vezető fenntarthatósági tanácsadója volt szakterületén. A BFF 1997-ben alakult az Egyesült Királyságban azzal a céllal, hogy segítséget nyújtson az országos szint alatti kalkulációkhoz. Számos szervezetnek nyújtottak segítséget és több mint 300 lábnyomtanulmányt készítettek, melyek között az egyik legjelentősebb a nagy sajtóvisszhanggal kísért londoni ökológiailábnyom-számítást bemutató kutatás. A BFF 2013-ban csatlakozott az Anthesis csoporthoz ${ }^{2}$, amely az Amerikai Egyesült Államok és Ázsia egyik vezető fenntarthatósági tanácsadó testülete (Szigeti, 2016).

Csutora (2011) szerint az ökológiai lábnyom vállalati szintű mérése bizonyult a leginkább problémásnak, ugyanis ebben az esetben áll rendelkezésre a legkevesebb felhozható példa, továbbá számos esetben az ökológiai lábnyom döntő részét az energiafelhasználás karbonlábnyoma adja. Ez kérdésessé teszi, hogy miért nem kizárólag a karbonlábnyomot alkalmazzuk vállalati mutatóként.

A lábnyomszámítás a korlátai miatt elsősorban a vállalat saját fejlődésének tervezésére és dokumentálására alkalmas módszer, amely segítséget nyújt a környezeti fejlesztések eredményeinek számszerüsítésében is (Harangozó, 2008). A lábnyom mint „közös mértékegység” segít a benchmarkban, továbbá számszerüsíthető a javulás mértéke és értékelhetővé válnak a stratégiák jövőbeli hatásai. Az ökológiailábnyom-kalkulációk további gyakorlati haszna lehet, hogy megtörténik a fogyasztási adatok áttekintése más szempontok szerint is, így olyan adatbázishibák/következetlenségek is feltárhatók, amelyekre addig nem került sor. Az ökológiai lábnyom közös mértékegységet jelenthet az ökohatékony beruházások és intézkedések értékelésére (Tóth et al., 2018). Ugyanakkor fontos kiemelni, hogy az ökohatékonysági fejlesztések esetében nagyon gyakran jelenik meg ún. a visszapattanó hatás, azaz a fajlagos környezetterhelés csökkenésével párhuzamosan, paradox módon, a fogyasztás növekedése következtében a kibocsátás abszolút volumene növekszik (pl. Harangozó, 2011).

Az ökológiai lábnyomon túl egyéb módszer is használható a vállalatok környezetterhelésének elemzésében. Az egyik irány a társadalmi metabolizmus, ezen belül pedig az anyagáram-elemzés (material flow analysis, MFA) módszertana. A társadalmi metabolizmus az ökológiai rendszer és a társadalom alrendszereinek kölcsönhatásait elemzi naturális dimenziókban (pl. energia, tömeg vagy földterület). Az így végezhető elemzés célja az erőforrások felhasználását meghatározó főbb tényezők azonosítása, a beavatkozási lehetőségek keresése, így a termelés anyaghatékonyságának és a gerjesztett környezetterhelés megállapítása, ami segítséget nyújthat a technológiai innováció lehetséges irányainak feltárásában (Karcagi-Kováts, 2008, Karcagi-Kováts, 2009; Karcagi-Kováts et al., 2016). A vizsgálat jelentős adatigénye miatt ennek elvégzése rendkívül munkaigényes.

\section{Alkalmazott módszertan}

Tanulmányunk alaphipotézise, hogy alkotható olyan könnyen kezelhető és megbízhatóan müködő ökológiailábnyom-kalkulátor, mely alkalmazható a kis- és középvállalkozói szektor számára. A létrehozott kalkulátor tesztelését hat, különböző "szektorban és szervezeti keretek 
között müködő" vállalkozással készített esettanulmányon végeztük.

A KKV-k számára készítendö/készített ökológiailábnyom-számítási módszertanok esetében két, egymással ellentétes előfeltétel határozható meg.

(1) Egyrészt a munkaigény minimalizálása érdekében kalkulátor használatához kizárólag a rendelkezésre álló vagy könnyen elöállítható adatkörök (pl. közmúszámlák, menetlevél kimutatások, felhasznált erőforrások kimutatása stb.) legyenek szükségesek. A meglévő (vezetői) információs rendszerekkel való integráció nemcsak a többlet munkaigény csökkentésében játszik szerepet, hanem a tapasztalatok alapján még a nagyvállalatok esetében is lehetnek (több) nagyságrendnyi hibák azon adatkörök esetében, melyek nem képezik külső vagy belső beszámolás tárgyát (Tóth et al., 2018).

(2) Másrészt a kalkulátor legyen specifikus, ne tartalmazzon túlzott egyszerüsítéseket (ld. Harangozó \& Szigeti, 2017). Habár a különböző megközelítések és a hozzájuk kapcsolódó fajlagos ökológiai lábnyomok önmagukban is tartalmazhatnak becsléssel elöállított adatokat, a naturáliában kifejezett kemény inputadatok (pl. x kWh elektromos áram vagy y liter gázolaj felhasználás stb.) a bizonytalansági szintet véleményünk szerint elfogadható szintre csökkentik. Az így kialakuló kombinált módszertan alkalmazása az adathiány kezelésére a vállalati számítások korábbi áttekintése alapján is elfogadható gyakorlat (Szigeti, 2016).

A kalkulátorban a vizsgált vállalkozások ökológiai lábnyomát öt lépésben határozzuk meg.

1. Első lépésként az energiahordozók (pl. földgáz, elektromos áram, gázolaj stb.) éves felhasználása alapján egy egyszerủ vállalati karbonlábnyomot számítunk. A számításhoz két olyan széles körủ adatbázison alapuló kalkulátort találtunk, aminek felépítése, szerkezete megfelel az elvárásoknak. Az egyik az Environmental Protection Agency (EPA) kalkulátora, míg a másik pedig National Energy Foundation-től ${ }^{3}$ (NEF) származik. A számítás alapjául az utóbbi kalkulátort használtuk, mert ez egyszerü és áttekinthető. Érdekes, hogy közös ,,uniós” kalkulátor jelenleg nincs, de a NEF kalkulátora, alapvetően DEFRA adatbázisra támaszkodva, Nagy-Britannia vállalkozásai számára kínál egyszerü ÜHG- és karbonlábnyom-számítási lehetőséget, de választható más ország is, illetve lehetőséget ad az uniós energiamix alkalmazására is. A kalkulátoron két korrekciót hajtottunk végre. Egyrészt a mértékegységeket a metrikus rendszerre váltottuk, másrészt a fajlagos üvegházhatású gáz (ÜHG) kibocsátási értékeket a brit kormány 2018. évi vállalati ÜHG kibocsátási tényezőivel ${ }^{4}$ frissítettük (ld. DEFRA, 2018). Az ökológiailábnyom-módszertan alapján (Lin et al., 2018) az ÜHG-értékek helyett CO2 értékével számoltunk, így a kalkulációnk óvatos becslésnek tekinthető. Másrészt a kalkulátort bővítettük a várhatóan releváns sorokkal. A kapott szénlábnyomértéket a GFN Footprint Intensity of Carbon faktorával számítjuk át átlagos termöképességü földterületre, azaz globális hektárra.

2. Második lépésként a karbonlábnyomot az étkezési lábnyommal egészítjük ki. A kalkuláció alapja, hogy a nők étkezéseinek ökológiai lábnyoma 0,475 , míg a férfiaké 0,551 globális hektár évente (Vetőné, 2014, p.117). Feltételezésünk szerint a munkavállalók az évi 255 munkanap során az aznapi étkezéseik felét a munkahelyükön költik el, így az étkezésekből 0,17-0,19 globális hektár/fö ökológiai lábnyom adódik. A kalkulátorban egyéb elkülönítést nem hajtunk végre, így a szellemi és a fizikai, vagy az idősebb munkavállalók fogyasztását azonosnak vesszük.

3. Harmadik lépésként, elvi lehetőségként figyelembe vehetjük a vállalkozás által felhasznált anyagok (pl. cement, faanyag, szappan stb.) előállítása során felmerült környezetterhelés ökológiai lábnyomát. Habár a lista nem tekinthető teljesnek, 625 különbözö inputot vettünk figyelembe, ami vélhetőleg lefedi a vállalkozások anyagszükségletének túlnyomó többségét. Itt a korlátot az vállalkozásoknál fellépő adathiány jelenti. A váltószámok a GFN aktuális adatbázisából (Lin et al., 2018) származnak.

4. Negyedik lépésként irodalmi adatok alapján az eredményt a vízfogyasztás lábnyomával árnyaljuk (Chambers et al., 2000), amelyhez csak a dolgozói létszámot vesszük figyelembe. A munkahelyi WC-használat, kézmosás, felmosás stb. alapján lábnyom értéke évente és dolgozónként 0,001 globális hektárra becsülhető. A nagyobb vízfogyasztás jellemzően a meleg víz előállításának energiafogyasztásában is megjelenik.

5. Az ötödik lépésben a beépített terület hektárban meghatározott nagyságát megszorozzuk az ekvivalencia(EQF), valamint a hozamfaktorral (YF), így megkapjuk az ökológiai lábnyom infrastruktúra-összetevőjét (Lin et al., 2018).

A második, a negyedik és az ötödik lépés jelenti azt a többletet, amivel kiléphetünk az ökológiai lábnyom szénlábnyom összetevőjének kereteiböl. Így látható az, hogy a munkaintenzív vállalati alkalmazkodásnak is van környezeti hatása, a kevés áramot felhasználó, ám nagy foglalkoztatotti létszámmal bíró vállalkozásnak is lehet jelentős ökológiai lábnyoma.

Az ökológiai számítások során valamennyi esetben fontos kérdés a tevékenységi kör lehatárolása. Ez a KKV$\mathrm{k}$ esetében különösen érdekes, ugyanis a vállalkozások tevékenysége gyakran az értéklánc egy kisebb szegletére korlátozódik. Habár a kalkulátor alkalmas lehet teljes értékláncok ökológiai lábnyomának felmérésére, az esettanulmányokban a vállalkozások hozzáadott értékének az

\footnotetext{
3 Az eredeti kalkulátor elérhetősége: http://www.carbon-calculator.org.uk/ letöltve: 2019. 03. 03.

${ }^{4}$ Az elemzésekben minden esetben a GHG Protocol szerinti Scope 3, azaz well-to-wheel tényezőket vettünk figyelembe.
} 
ökológiai lábnyomát vizsgáltuk. Véleményünk szerint ez a megoldás adja a leginkább megbízható eredményeket, ugyanis a vállalkozások a saját hozzáadott értékükről rendelkezhetnek megbízható információkkal és lehetnek képesek befolyásolni a folyamatokat. Mindazonáltal fontos kiemelni, hogy a nagyvállalatok a saját tevékenységük és kibocsátásuk optimalizációja érdekében kiszervezhetik a kis- és középvállalkozásoknak a környezetterhelö, munkaigényes, vagy alacsony reputációjú tevékenységeket, melynek következtében a KKV-k fajlagosan környezet szempontból károsabbnak tünhetnek. Ez a jelenség az országos ökológiailábnyom-értékeknél már megjelenik, a gazdaságilag fejlett országok úgy érnek el növekvő GDP-t és csökkenő ökológiai lábnyomot, hogy közben más országoknál jelennek meg a káros hatások (Szigeti et al., 2017).

Az ökológiai lábnyom nagyságát összevetettük a vállalkozások gazdasági teljesítményével. Véleményünk szerint a nettó árbevétel két okból sem alkalmas a vállalati ökológiai lábnyom gazdasági teljesítménnyel való összevetésére. Egyrészt az egyes szektorok sajátosságai következtében az árbevétel jelentősen eltérhet (pl. kereskedelem, feldolgozóipar, tanácsadás stb.). Másrészt mivel a KKV-k a teljes értéklánc egy-egy szakaszára specializálódhatnak, az árbevétel nem feltétlen tükrözi a valós teljesítményt, ugyanis az értékláncban részt vevő cégek árbevételét a teljesítményükön kívül egyéb tényezök (pl. méretük, alkupozíciójuk stb.) is lényegesen befolyásolhatja. Ez az értéklánc egyes vállalatainak ökológiailábnyom-számításánál felvetheti a kettős elszámolás lehetőségét (ld. Szigeti, 2016, p. 171). Ilyen lehet például, hogy egy adott félkész termékkel kapcsolatosan a szállítás kibocsátásait mind a beszállító, mind a megrendelő vállalkozás elszámolja. Ennek megfelelően az elemzésekben a vállalkozások hozzáadott értékét vesszük alapul, mely álláspontunk szerint a gazdasági teljesítmény pontosabb becslését szolgáltatja, mint az értékesítés nettó árbevétele. A vállalkozás hozzáadott értékét a rendelkezésre álló számviteli adatok alapján, a személyi jellegű ráfordítások, az értékcsökkenés és az adózás elötti eredmény összegeként határoztuk meg (Veress et al., 2018, p. 218).

\section{Eredmények \\ Az esettanulmányok}

A kalkulátor tesztelésére hat esettanulmányt készítettünk. A vállalkozások kiválasztása személyes kapcsolatok alapján történt, a kapott eredményeket anonim módon közöljük. Ugyanakkor a kiválasztás során törekedtünk arra, hogy a tevékenységi körök, illetve a működési formák lehetőség szerint minél szélesebb körét megvizsgáljuk. A következőkben röviden bemutatjuk a vállalkozások föbb jellemzőit. A vállalkozások főbb adatait a tanulmány mellékletében közöljük.

Az építőipari cég nyugat-magyarországi székhellyel rendelkező korlátolt felelősségű társaság. A vállalkozás elsődleges tevékenysége ipari csarnokok generálkivitelezése, de egyéb építőipari munkálatokat is vállal. A cég 35 föt foglalkoztat közvetlenül, éves árbevétele 3-3,5 milliárd forint körül alakul. Az építőipar jellemzői miatt az egyes évek ökológiai lábnyoma között óriási különbség lehet, attól függően, hogy milyen projektet nyer el a vállalat. Más- részt az éves lábnyom értelmezése is problémát jelenthet, itt relevánsabb lehet egy ,projektlábnyom” számítása, ami akár több év hatását is tartalmazza.

A szőlőoltványok előállításával foglalkozó cég szintén nyugat-magyarországi székhellyel rendelkező korlátolt felelősségü társaság. A cég az oltványok előállítása és nevelése mellett ültetvények létrehozását is vállalja Magyarországon és külföldön egyaránt. A cég éves nettó árbevétele 350 millió forint körül alakul, 35 föt foglalkoztat.

A vizsgált fodrászat Győrben található, egy bérelt üzlethelyiségben két egyéni vállalkozó dolgozik. A vállalkozók éves nettó árbevétele 13 millió forintra tehetö. A kalkuláció egyik kihívása, hogy a két vállalkozó áram és vízfogyasztása nem különíthető el, mivel egy-egy méröóra van a közösen bérelt helyiségben.

A gyógyszertár egy anyapatika és három fiókpatikát üzemeltető kelet-magyarországi betéti társaság. A cég egy gyógyszerészt és három alkalmazottat foglalkoztat, éves árbevétele 125 millió forint körül alakul. Itt jelentős nagyságrendet jelent az egyes telephelyek közötti közlekedés, ami nem iparág-, hanem müködésspecifikus jellemző.

A büfé egy budapesti egyetemen belül, egyéni vállalkozás keretében müködik. A vállalkozás egy föt foglalkoztat, becsült éves nettó árbevétele 6,5 millió forint. Ennél a vállalkozásnál problémát jelent, hogy a saját áramfogyasztásukról nincs információnk, ez csak a gépek müszaki paraméterei alapján becsülhető.

A fuvarozó cég Budapesten müködik, korlátolt felelősségű társaságként. A cég komplex logisztikai szolgáltatást ajánl a nyugat-európai országok, Magyarország és Kelet-Európa között. Fontos kiemelni, hogy a vállalkozás a szállítást külső szolgáltatóktól veszi igénybe, saját tehergépjármüvel nem rendelkezik. A cég éves árbevétele 190 millió forint körül alakul és két föt foglalkoztat.

Tapasztalataink szerint az esettanulmányokban vizsgált vállalkozások elsősorban anyagi, hatékonysági szempontokat mérlegelve bocsátkoztak az ökológiai szempontból hatékonyabb müködést lehetővé tevő megoldások megvalósításába (pl. faelgázosító kazán, alacsony fogyasztású gépjárművek, LED-es világítás stb.). E fejlesztések - a pénzben is kifejezhető megtakarítások mellett - a vállalkozás ökológiai lábnyomát is jelentösen mérsékelték. A fejlesztésekre vonatkozó tervekben a gazdasági hatékonyság szempontja mellett a környezeti megfontolások szintén megjelentek, melyek kiválasztási folyamatát a tulajdonos/menedzserek (müszaki) ismeretei, attitüdjei jelentős mértékben befolyásolták (pl. elektromos autó vagy napelemek jövőbeni beszerzése). Eredményeink két korábbi, hazai kutatás eredményeit is alátámasztják, azaz

- a KKV-k fejlesztési döntéseiben a környezeti szempontból hatékony megoldásokról rendelkezésre álló információk kritikus tényezőnek tekinthetők (Széchy \& Zilahy, 2018),

- a magyarországi KKV-k esetében is elkülöníthető egy olyan, jelentős számú vezetői réteg, mely modern, a stakeholdereket is figyelembe vevő vállalatirányítási, vállalati társadalmi felelősségvállalási (CSR) attitűdökkel rendelkezik (Benedek \& Takácsné György, 2016). 
A vizsgált vállalkozások egy före jutó ökológiai lábnyoma alapján egy magasabb és egy alacsonyabb ökológiai lábnyomú csoportra oszthatók (ld. 1. ábra). Érdemes kiemelni, hogy a fuvarozó cég fajlagos lábnyoma az egyik legalacsonyabb, melynek oka, hogy a cég a szállítást külső partnerei végzik, így a szennyezés is a cég kapuin kivül jelentkezik. Ezzel épp ellentétes tendencia figyelhető meg a fodrászat esetében. A viszonylag nagy lábnyomot a fodrászok autós ingázása, a használt nagyteljesítményủ gépek, valamint az alkalmazottak alacsony száma okozza.

\section{1. ábra A vizsgált vállalkozások egy főre jutó ökológiai} lábnyoma és annak belső megoszlása (gnm/fő)

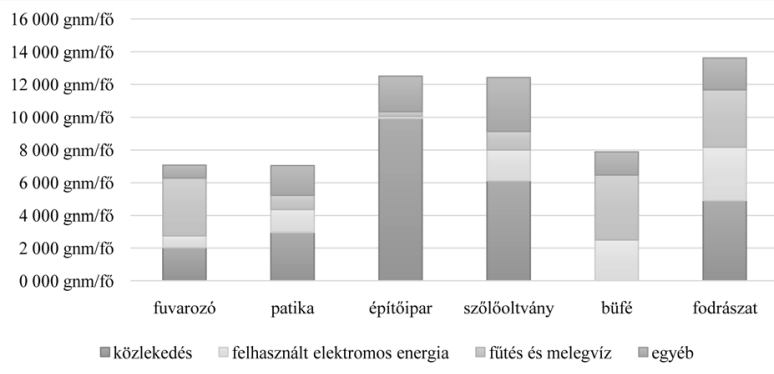

A tapasztalatok szerint a vállalkozások ökológiai lábnyomának jelentős részét a szénlábnyom teszi ki. Ezt a megfigyelést az esettanulmányok teljes mértékben alátámasztják - a közlekedéssel, elektromos árammal, illetve a fütéssel és a melegvíz-elöállítással kapcsolatos erőforrás-felhasználások legalább a teljes lábnyom 70 százalékát teszik ki (ld. 2. ábra). Érdekes kiemelni, hogy a büfé ese-tében a közlekedés klímasemleges, ugyanis a büfés kerékpárral jár dolgozni.

\section{2. ábra A vizsgált vállalkozások ökológiai lábnyomának belső megoszlása (\%)}

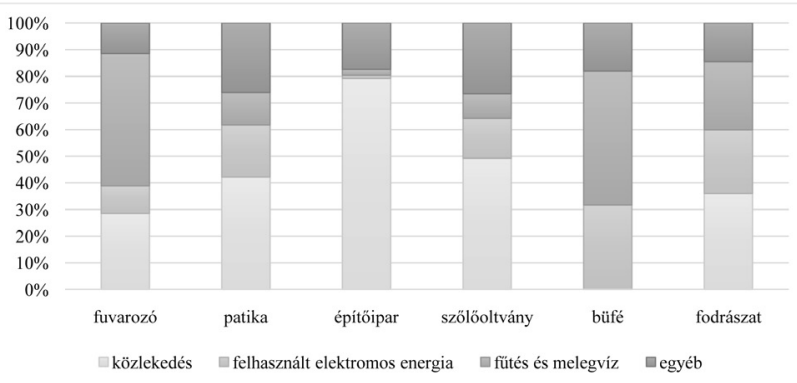

A gazdasági és az ökológiai hatékonyság elemzése problémát okozott, hogy az esettanulmányokban vizsgált vállalkozásokról elérhető információk köre rendkívül eltérő. A társas vállalkozások (építőipari, fuvarozó, valamint szőlőoltvány-termelő cég, patika) esetén a gazdasági adatok a közzétett számviteli beszámolók alapján évekre visszamenöleg rendelkezésre álltak, így a hozzáadott érték számítása könnyen kivitelezhető. Ugyanakkor tapasztalatként fogalmazható meg, hogy az ökológiai lábnyom számításához szükséges adatok a beszámolókban nem állnak rendelkezésre, azok további, egyedi adatgyüjtést igényelnek, így az időbeli elemzés ez esetben nem valósítható meg. A fennmaradó két vizsgált szervezet közül a fodrászatot egyéni vállalkozók működtetik, míg a büfé egy nagyobb intézmény részegységeként müködik. Esetükben számviteli jellegủ adat sem állt rendelkezésre, így a gazdasági jellegű adatokat becsléssel állapítottuk meg, ami szükségszerüen torzításokat jelenthet.

Kocsis (2010) makrogazdasági elemzésének analógiájára összevetettük a vizsgált szervezetek gazdasági és ökológiai hatékonyságát. Az ökológiai hatékonyság reciprokát, az anyagintenzitást egységnyi hozzáadott értékre jutó ökológiai lábnyomként ${ }^{5}$, míg a gazdasági hatékonyságot egy före jutó hozzáadott értékként definiáltuk. Az elemzésben kedvezö értéknek tekinthető, ha egy vállalkozás alacsony anyagintenzitás mellett magas fajlagos hozzáadott értéket termel (3. ábra).

\section{3. ábra Az esettanulmányokban vizsgált vállalkozások anyag- intenzitása (gnm/eFt) és gazdasági hatékonysága (eFt/fő)}

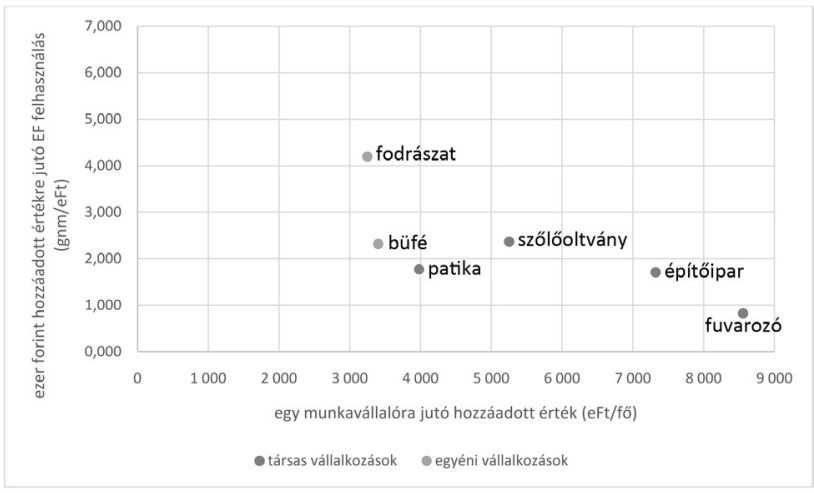

Talán meglepő módon a legkedvezőtlenebb mutatókkal a fodrászat rendelkezik, melyet a napi autós ingázás jelentette üvegházgáz-kibocsátás okoz. Anyagintenzitás tekintetében a büfé, a patika, a szőlőoltvány-termelő, valamint az építőipari cég hasonló értékeket mutat, jelentős eltérés a gazdasági teljesítményben mutatkozik. A büfé relatíve alacsony pénzügyi teljesítményét az ,egyszemélyes vállalkozás" jellege, a becslési módszertan és a szezonális értékesítés okozhatja. Ugyanezt a patika esetében a területi elhelyezkedés (alacsony jövedelmi szintü, kelet-magyarországi kistelepülések) magyarázhatja. A szőlöoltványtermelö, illetve az építőipari cég esetében magas fajlagos hozzáadott értékről beszélhetünk. Érdekes kiemelni, hogy a legjobb teljesítmény a fuvarozó esetében tapasztalható a tényleges szállítási tevékenység kiszervezése miatt.

\section{Diszkusszió}

Kutatásunk hipotézise volt, hogy létrehozható olyan ökológiailábnyom-kalkulátor, mely a kis- és középvállalkozások számára is minimális többlet adatszolgáltatás mellett lehetővé teszi az ökológiai lábnyom megbízható kiszámítását. Az esettanulmányok alapján az általunk létrehozott kalkulátor teljesíti ezt a feltételt. Mivel az ökológiailábnyom-kalkulátorok ered-

\footnotetext{
${ }^{5}$ A nagyságrendek érzékeltetése végett a viszonyszám mértékegysége globális négyzetméter/ezer forint.
} 
ményei a helyspecifikus értékek és egyszerüsítések következtében jelentős szórást mutatnak, (Harangozó \& Szigeti, 2017), a lábnyomok összehasonlítása csak azonos kalkulátorral (és módszertannal) számított értékek esetében történhet. Ennek megfelelően a kifejlesztett kalkulátort további, több szektorra kiterjedő tesztelésnek szükséges még alávetni. A tesztelés, majd az azt követő éles üzem lehetőséget teremt egy olyan benchmark adatbázis létrehozására, mely a kitöltő vállalkozások anonim adatai alapján segít meghatározni az egyes szektorokban működő vállalkozások ökológiai lábnyomának várható értékét. A vállalkozások számára azért is hasznos a módszer, mert így képet kaphatnak arról, mely területen a legnagyobb a környezetterhelésük. Még ha nem is szakértői a témának, a területen való nagyobb tudatosság már önmagában pozitív lehet.

További problémaként jelölhető meg, hogy az esettanulmányokban az ökológiai lábnyom számítása egy évre történt meg. A tapasztalatok alapján a vállalkozások ökológiai lábnyoma viszonylag stabil, így a dinamikus összehasonlítás az eredmények kisebb korrekciójával nagyságrendileg pontosan elvégezhető. Ugyanakkor az építőipari cég esetében a vállalt projektek függvényében a lábnyom nagysága akár jelentősen is változhat, így a dinamikus elemzésekhez a lábnyomszámítást évről évre szükséges elvégezni. Javaslatunkat az is alátámasztja, hogy az ökológiailábnyom-mutató használatával összefüggő általános ajánlás is az időbeli összehasonlítást preferálja (Kovács et al., 2017; Szigeti, 2016). Véleményünk szerint feltételezhető, hogy több hasonló szektor is létezhet, mindazonáltal az esettanulmányok alapján erre vonatkozóan megalapozott eredménnyel nem rendelkezünk.

A nagyvállalatok esetében az ökológiai lábnyom számításához szükséges adatok a meglévő számviteli nyilvántartásokból, illetve a belső információs rendszer kimutatásaiból viszonylag gyorsan és csaknem teljes körüen előállíthatók. Ugyanakkor kis- és középvállalkozások nem, vagy csak alig tesznek közzé az ökológiai lábnyom számításához szükséges adatokat. Az esettanulmányokban vizsgált mikro-, illetve kisvállalkozásokat személyes kapcsolat alapján kerestük meg, a kalkulációhoz szükséges adatokat az interjúzott személyektől kértük, akik ezeket a belső információkat szívességből gyüjtötték ki és adták át. Az egyéni vállalkozóknál a számlák és a belső kimutatások sem álltak rendelkezésre. Az ökológiailábnyom-számítást a géppark és a tevékenység ismeretében becsültük, melynek alapját a vállalkozók által adott adatok, illetve iparági átlagok képezhetik. Ebből következően a kapott eredmények megbízhatósága alacsonyabb.

Fontos kiemelni, hogy az általunk vizsgált esetek viszonylag tiszta eseteket példáznak. A kisebb vállalkozások, vagy egyéni vállalkozások esetében a vállalkozás és a magánszféra határa összemosódhat. A leggyakoribb példa a céges eszközök (pl. mobiltelefon, számítógép, autó stb.) magáncélú felhasználása. Jó példa erre, hogy az esettanulmányban vizsgált fodrász a törölközőket és egyéb eszközöket otthon mossa, így a kapcsolódó energia- és vízfogyasztás is ott merül fel. Ugyanakkor egy egyetemen múködö büfé esetén például a bérleti jogviszony következtében nem feltétlen áll rendelkezésre hozzávetőleges kimutatás a fütéshez, illetve a melegvíz előállításához használt földgáz mennyiségéről, vagy az elektromos áram felhasználásról.

\section{Következtetések}

A jövőben a kalkulátort online formában elsőként további tesztelési céllal, majd éles üzemben tervezzük elérhetővé tenni. A kitöltés során kapott anonim gazdasági és ökológiailábnyom-adatok elemzése alapján megállapíthatóvá válhat a különböző szektorok átlagos ökológiai hatékonysága, illetve fajlagos hozzáadott értéke. Ez a benchmarkérték kiindulópontját jelentheti a kitöltők esetleges ökológiai szempontú folyamatracionalizálásához is. Az adatbázis másik előnye, hogy néhány év elteltével lehetőséget biztosíthatna a dinamikus elemzésekhez.

Amennyiben a kormányzat számára fontos, hogy képet kapjon a KKV-szektor környezeti teljesítményéröl, a környezeti, illetve társadalmi adatok nagyvállalati jelentéstételben való egyre gyakoribb megjelenéséhez kapcsolódva javasoljuk, hogy az ökológiailábnyom-számításhoz szükséges főbb inputadatok természetes mértékegységben és a korábbi évek adataival összehasonlítható módon jelenjenek meg a legalább öt fős társas vállalkozások éves (számviteli) beszámolóinak kiegészítő mellékletében. A KKV-szektor jellemzőihez illeszkedve ez a jelentéstétel jelentősen elmaradna a nagyvállalatoktól elvárt szinttől (Málovics, 2011), így az nem jelent a vállalkozásoknak túlzott adminisztrációs terhet. Az általunk javasolt főbb adatok körébe tartozik például a felhasznált földgáz energiatartalma, a vásárolt villamosenergia mennyisége, vagy az egyes céges gépjármüvek adott éves futásteljesítménye.

Kutatásunk számára két lehetséges további kutatási irány emelhető ki. Az egyik a létrehozott ökológiailábnyom-kalkulátor tesztelések során feltárt igények szerinti továbbfejlesztése, olyan speciális területeken, mint például az építőipari projektek ökológiai lábnyoma. A másik fejlesztési lehetőség a nagyobb, statisztikai módszerekkel elemezhető adatbázis alapján (ágazati) benchmark adatok meghatározása.

\section{Felhasznált irodalom}

Benedek, A., \& Takácsné György, K. (2016). A felelös vállalatirányítás személyi tényezői: A CSR-központ felelős vállalatvezetők attitüdjének vizsgálata a kis- és középvállalatok körében. Vezetéstudomány/Budapest Management Review, 47(1), 58-67.

Chambers, N., Simmons, C., \& Wackernagel, M. (2000). Sharing nature's interest: Ecological footprints as an indicator of sustainability. London, UK: Routledge.

Csutora M. (2011). Az ökológiai lábnyom számításának módszertani alapjai. In Csutora M. (szerk.), Az ökológiai lábnyom ökonómiája (pp. 6-16). Budapest, Magyarország: Aula Kiadó.

Harangozó, G. (2008). Mitől zöld egy vállalat - avagy mit is jelent a jó környezeti teljesítmény? Vezetéstudomány, 39(1), 27-36.

Harangozó, G. (2011). A visszapattanó hatás jelentősége az energiafelhasználás csökkentésében. In Csutora, M. (szerk.), Az ökológai lábnyom ökonómiája (pp. 108118). Budapest, Magyarország: Aula Kiadó.

Harangozó G., \& Szigeti, C. (2017). Corporate carbon footprint analysis in practice: With a special focus on validity and reliability issues. Journal of Cleaner Production, (167), 1177-1183. http://dx.doi.org/10.1016/j.jclepro.2017.07.237 
Karcagi-Kováts A. (2008). Az anyagáram elemzés indikátorai és alkalmazásuk lehetőségei az agrár- és fenntarthatósági stratégiákban. In 50. Jubileumi Georgikon Napok (pp. 1-8). Pannon Egyetem Georgikon Kar, Keszthely, Magyarország.

Karcagi-Kováts A. (2009). Az MFA mutatók alkalmazásának lehetőségei a települési fenntarthatóság jellemzésében. Agrártudományi Közlemények Acta Agraria Debreceniensis, (34), 107-116.

Karcagi-Kováts A., Kovács I., Dombi M., \& Kuti I. (2016). A gazdasági válság lehetséges környezeti ajándékhatásai a visegrádi négyek országaiban. Közép-Európai Közlemények, 9(2), 51-60.

Kocsis, T. (2010). „Hajózni muszáj!” A GDP, az ökológiai lábnyom és a szubjektív jóllét stratégiai összefüggései. Közgazdasági Szemle, 57(6), 536-554.

Kovács Z., Szigeti C., Egedy T., Szabó B., \& Kondor A. (2017). Az urbanizáció környezeti hatásai: Az ingázás ökológiai lábnyomának változása a budapesti várostérségben. Területi Statisztika, 57(5), 469-494. http:// dx.doi.org/10.15196/TS570501

Lin, D., Hanscom, L., Martindill, J., Borucke, M., Cohen, L., Galli, A., ...Wackernagel M. (2018). Working guidebook to the national footprint accounts. Oakland, New Zealand: Global Footprint Network.

Málovics, Gy. (2011). A vállalati fenntarthatóság értelmezéséröl. Szeged, Magyarország: JATEPress.

McDonald, G.W., \& Patterson, M.G. (2004). Ecological footprints and interdependencies of New Zealand regions (analysis). Ecological Economics, (50), 49-67.

Stiglitz, J., Sen, A., \& Fitoussi, J.-P. (2009). Report by the commission on the measurement of economic performance and social progress. http://www.stiglitz-sen-fitoussi.fr/documents/rapport_anglais.pdf
Széchy, A., \& Zilahy, Gy. (2018). Vállalati környezeti menedzsment Magyarországon: Az elmúlt húsz év tapasztalatai. In Környezet, gazdaság, társadalom. Tanulmányok Kerekes Sándor 70. születésnapja tiszteletére (pp. 168-179). Kaposvár, Magyarország: Kaposvári Egyetem Gazdaságtudományi Kar Kaposvár.

Szigeti, C. (2016). Az ökológiai lábnyom határai. Budapest, Magyarország: Typotex.

Szigeti, C., Tóth, G., \& Szabó, D. R. (2017). Decoupling: Shifts in ecological footprint intensity of nations in the last decade. Ecological Indicators, (72), 111-117. http://doi.org/f9xb5x

Tóth, G., Szigeti, C., Harangozó, G., \& Szabó, D.R. (2018). Ecological footprint at the micro-scale: How it can save costs: The case of ENPRO. Resources, 7(3), 45. https://doi.org/10.3390/resources7030045

Tóth G., \& Szigeti C. (2016). The historical ecological footprint: From over-population to overconsumption. Ecological Indicators, (60), 283-291. https://doi. org/10.1016/j.ecolind.2015.06.040

Vetőné Mózner, Zs. (2014). Úton a fenntartható élelmiszerfogyasztás felé (PhD-értekezés). Budapesti Corvinus Egyetem, Budapest, Magyarország. http://phd.lib.unicorvinus.hu/724/1/Vetone_Mozner_Zsofia_dhu.pdf

van den Bergh, J.C.M. J., \& Verbruggen, H. (1999). Spatial sustainability, trade and indicators: an evaluation of the ecological footprint. Ecological Economics, (29), 61-72.

Veress, A., Borzán, A., \& Kardos, B. (2018). Számvitel menedzsereknek és informatikusoknak. Budapest, Magyarország: Saldo Kiadó.

Wackernagel, M., \& Rees, W. (1996). Our ecological footprint. Reducing Human Impact on the Earth. Philadelphia, PA: New Society.

Publishers

\section{Melléklet}

1. táblázat Az esettanulmányokban vizsgált vállalkozások főbb mutatói a 2017-es évre vonatkozóan (különböző mértékegységek, saját gyűjtés)

\begin{tabular}{|c|c|c|c|c|c|c|c|}
\hline mutatók (2017) & me. & fuvarozó & patika & építőipar & $\begin{array}{c}\text { Szőlő- } \\
\text { oltvány }\end{array}$ & büfé & fodrászat \\
\hline $\begin{array}{l}\text { alkalmazottak } \\
\text { száma }\end{array}$ & fö & 2 & 4 & 36 & 35 & 1 & 2 \\
\hline nettó árbevétel & eFt & 190324 & 126621 & 3139997 & 362131 & $8504 *$ & $12992 *$ \\
\hline $\begin{array}{l}\text { hozzáadott } \\
\text { érték }\end{array}$ & $\mathrm{eFt}$ & 17115 & 15919 & 263589 & 183878 & $5102 *$ & $6496^{*}$ \\
\hline $\begin{array}{l}\text { ökológiai } \\
\text { lábnyom }\end{array}$ & gha & 1,42 & 2,82 & 45,07 & 43,53 & 0,79 & 2,73 \\
\hline $\begin{array}{l}\text { földgáz- } \\
\text { fogyasztás }\end{array}$ & $\mathrm{kWh}$ & 9959 & 4879 & 11280 & 74351 & 5613 & 9866 \\
\hline $\begin{array}{l}\text { elektromos- } \\
\text { energia- } \\
\text { fogyasztás }\end{array}$ & $\mathrm{kWh}$ & 1824 & 6874 & 6157 & 81496 & 3115 & 8123 \\
\hline $\begin{array}{l}\text { gázolaj- } \\
\text { fogyasztás }\end{array}$ & liter & 165 & 0 & 37772 & 11596 & 0 & 0 \\
\hline $\begin{array}{l}\text { benzin- } \\
\text { fogyasztás }\end{array}$ & liter & 0 & 1677 & 1423 & 0 & 0 & 1383 \\
\hline
\end{tabular}

* becsült adatok 